\title{
Thiamine-responsive maple syrup urine disease
}

INSERM

\section{Source}

INSERM. (1999). Orphanet: an online rare disease and orphan drug data base. Thiamineresponsive maple syrup urine disease. ORPHA:268184

Thiamine-responsive maple syrup urine disease (thiamine-responsive MSUD) is a less severe variant of MSUD (see this term) that manifests with a phenotype similar to intermediate MSUD (see this term) but that responds positively to treatment with thiamine. 